\title{
Article
}

\section{The Alternative World of the Proud Non- Drinker: nineteenth-century public displays of Temperance}

\author{
Mcallister, Annemarie \\ Available at http://clok.uclan.ac.uk/13245/ \\ Mcallister, Annemarie ORCID: 0000-0003-0615-3262 (2014) The Alternative \\ World of the Proud Non-Drinker: nineteenth-century public displays of \\ Temperance. Social History of Alcohol and Drugs, 28 (2). ISSN 1930-8418
}

It is advisable to refer to the publisher's version if you intend to cite from the work. http://dx.doi.org/10.1086/SHAD28020161

For more information about UCLan's research in this area go to http://www.uclan.ac.uk/researchgroups/ and search for < name of research Group>.

For information about Research generally at UCLan please go to http://www.uclan.ac.uk/research/

All outputs in CLoK are protected by Intellectual Property Rights law, including Copyright law. Copyright, IPR and Moral Rights for the works on this site are retained by the individual authors and/or other copyright owners. Terms and conditions for use of this material are defined in the policies page.

\section{CLoK}

Central Lancashire online Knowledge www.clok.uclan.ac.uk

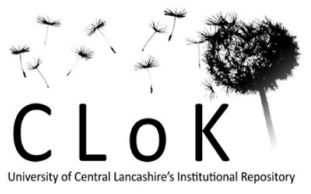


Annemarie McAllister

The Alternative World of the Proud Non-Drinker: nineteenthcentury public displays of Temperance

In the midst of studies of public drinking in the nineteenth century, it is important to examine the insistent public presence of those who did not drink - perhaps the most significant social and political group of that century, the temperance movement. With an estimated membership of at least six million members in the United Kingdom by 1900, the various groups which formed the national movement all shared the conviction that saving their fellow members of society from the evils of drink was a moral duty. ${ }^{1}$ Thus, for the convinced, membership was not merely a matter of not consuming alcoholic beverages, but also demanded the active public display of temperance, to participate in the complex life of the community as a shaping force. By their presence on the streets, advocates were taking their argument to 'a particular space, a landscape that could be exploited effectively through the collective performance of particular rituals to communicate, legitimise, and politicize values.'2

'TEMPERANCE' IN THE UNITED KINGDOM

Virginia Berridge identifies four major phases in the nineteenth century UK temperance movement, which is a useful framework. ${ }^{3}$ Initially it bore its original meaning of 
moderation, and by 1830 there were estimated to be around 127 temperance societies in England with a total membership of up to 23,000 members, most of them in the manufacturing districts of the north. All advocated abstaining from spirits and indulging in brewed liquors sensibly, and were dominated by middle-class members. However, government promotion of beerdrinking as an alternative led to a realisation that this approach was not effective and indeed resulted in increased public drunkenness. ${ }^{4}$ The signing of a total abstinence pledge in 1832 by seven men in Preston was in itself produced as a public event, as the original signing took place in August, but this was followed by an "official signing" on lst September witnessed by hundreds of members of the existing Preston Temperance Society. It was this latter date which was, subsequently, kept as a significant anniversary for later public events. ${ }^{5}$ Joseph Livesey, one of the original pledgesigners, was a gifted publicist and entrepreneur whose flair for public display can be illustrated by his often-performed "Malt Liquor lecture." Before the gaze of huge audiences, to prove that beer contained alcohol and little nutrition (both facts popularly denied at the time), he distilled the alcohol from a quart of ale and, having contrasted it with bread, then set it ablaze to entertain, as well as convince, those watching $\cdot 6$ 
Total abstinence, or teetotalism, caught the imagination of millions of people, especially working people who spent proportionately the largest part of their income on drink. This can be seen as the second, radical, phase of UK temperance, and though a few organisations such as the UK Alliance and the Church of England Temperance Society allowed moderation, the majority of temperance organisations advocated teetotalism. Moderation is an imprecise ambition rather than a clear guideline, and thus difficult to maintain. In contrast, the crusade to avoid all alcohol provides a sense of clarity in all situations. Moreover, unlike the genteel moderation societies, the teetotal movement welcomed reformed drunkards, and meetings often featured testimonies of past infamy and intensely emotional promises of change which produced intense "conversion" experiences in large audiences. Such a charged atmosphere gave intensity to the individual's promise, to the new life and identity which would be conferred by the pledge, and to the sense of duty to oppose alcohol. Moreover, the creed of total abstinence was in many ways a radical belief, challenging both accepted custom and the capitalist power of brewers, and Livesey remarked in his Reminiscences that "the greatest number of our active spirits were working men."7 It is therefore not surprising that reforming groups such as Chartists, Owenites and the Rochdale Pioneers numbered many abstainers as members, and debated whether to ally their movements formally with teetotalism. 
The temperance movement's reforming zeal was often, although not always, linked to dissenting religious belief as well as the desire for social amelioration, resulting in committed and energetic workers. But "the radical belief in individual improvement ... vulnerable to assimilation to cultural patterns determined by the middle-class," along with the increasing move to religious respectability, led to an increasing domination of the movement, in some areas, by the middle classes. 8 This, as well as influence from Northern America, was a factor in the move to its third and fourth phases as identified by Berridge, the focus on political tactics and prohibition. Public opinion became a crucial factor in the spread of influence, as well as serving to increase membership numbers. This was achieved by a range of strategies, but a key factor was the success of many temperance groups in developing a "brand" and harnessing developing technologies served to increase their public visibility. Advances in technology in the second half of the nineteenth century, such as those in the fields of optics, printing, and distribution, coincided with the rapid growth of the movement, to ensure that magic lantern shows, periodicals, tracts, pledges, and visible membership markers such as distinctive clothing or badges spread the word and kept temperance publicly visible. The increasing public recognition of brands and slogans was made good use of by temperance campaigners to gain converts and sustain a temperance presence 
in the public arena. "We live in an age of advertising, and what more resplendent and dazzling advertisement could we have than our gaudy collars?" wrote a Welsh teetotaller in $1875 .{ }^{9}$ Although the movement was far from monolithic, and experienced many schisms, individual groups often made common cause in their drive to fight alcohol and to persuade more people to do so. Organisations such as the Rechabites, who provided financial security for teetotallers; the UK Alliance, which promoted political solutions such as prohibition; and the Band of Hope, for children and young people, had specific targets but a shared mission. Thus the temperance movement developed a large constituency, which felt it a duty to gain converts and to challenge alcohol - and to create an alternative world in many respects. The public performance of temperance falls into the category of Wyn Grant's "outsider group" of pressure groups who do not have direct access to government and need to gain public legitimacy and expand a constituency - ironically, the example Grant gives is the brewing industry in the twentieth century. ${ }^{10}$

To date, writers on the history of the UK temperance movement have made relatively little exploration of its public dimension. Brian Harrison mentions buildings, regalia and processions several times and quotes a fairly lengthy account of a gathering of teetotallers in North Wales in 1837 in his magisterial history, Drink and the Victorians.11 But these 
references are scattered throughout the book, and used in support of arguments rather than being studied in their own right. Lilian Lewis Shiman makes occasional mention of processions in The Crusade Against Drink in Victorian England, and indeed -processions seem to be the most frequently discussed aspect of recent temperance history, for example Paul O'Leary devoting a chapter to Welsh temperance processions in Claiming the Streets: Processions and Urban Culture in South Wales, c.1830-1880.12 The architectural historian Andrew Davison has also carried out an excellent survey of types of buildings in 'Try the alternative': the built heritage of the temperance movement."13

Writers on temperance history in the US have commented on the public presence of the temperance movement, but due to its differing development, it met much more public antagonism than in the UK, where levels of coercion were much less. Jack Blocker sums up the activities of US temperance activists,

They conducted surveys, prayed, sung, marched on saloons, marched in parades, marched in demonstrations, and attended meetings and conventions. They destroyed the contents of saloons with axes, hatchets, hammers, rocks, and metal bars...They were harassed, mocked, beaten, hosed down, hung in effigy, shot at, and shot down. ${ }^{14}$ 
The Washingtonians were closest, perhaps, to the early

[British] teetotallers who left such a strong impression on the UK temperance movement, aiming to re-create the sociality and fellowship of the "grog-shop" and organising frequent public entertainments as described in Ian Tyrrell's Sobering Up. ${ }^{15}$ Paul D. Sanders argues that "it was the entertainment aspects, along with their secular and suasionist views, that eventually led to the demise of the Washingtonian movement," with accusations of "programming disgusting rituals."16 In his study of temperance song, The Well-Tempered Lyre, George W. Ewing speaks of "the parades and songs, the poems and the pageantry," but then concentrates on poetry and song, and the excellent studies of the US Temperance movement by Gusfield, and Martin, for example, do not cover the public performance of total abstinence.in this dimension. ${ }^{17}$ However, valuable light can be shed on the influence of the UK temperance movement by a better understanding of such events in the context of the continual inscription of presence by such means as the costumes of actors, and their created environment. TEMPERANCE ON THE STREETS

The exploration of the public performance of temperance begins with the physical environment. If the centre of cities can be considered as 'a stage for the display of social identity and difference,' as Simon Gunn asserts, then consideration must be given to the stage setting, or the buildings. Such "landscapes of power" draw on shared 
experiences but also inscribe and reiterate power, whether of local or national authority, personal or institutional influence, or simply possession of wealth or property. ${ }^{18}$ The many temperance buildings in cities, towns and villages acted as a constant public declaration of the power of the temperance movement. There were, of course, practical reasons for their construction. In a society where public houses, as the name suggests, are the main places to meet, eat, and stay as well as drink, total abstainers needed alternative places to carry out activities. This was the first reason for the creation of an alternative world, and buildings were some of the earliest public presences of the temperance movement. As well as the need for physical accommodation, gathering with other like-minded people would provide validation as well as support and companionship. This could also be found in regular temperance society meetings, and with time temperance teams or clubs were set up and temperance fetes, galas and performances offered further options for entertainment and re-affirmation important functions, when keeping to the pledge might prove difficult after the first enthusiasm. Outside this enclosed world, the excitement and interest of public events would thereby both attract and retain members. The public buildings, events or practices discussed in this paper, whether intended for a teetotal or general audience, all worked to inscribe the power of the temperance movement in the centres of cities, towns and villages. 
Total abstainers can be seen to have carried out a strategic "occupation" of, for example, the streets, taverns and coffee houses - all cited by Habermas as spaces in which private individuals meet to create public opinion, or the "public sphere."19 These particular spaces have long since been associated with radical protest and opposition, "Historians of the late eighteenth and early nineteenth century radical movements have long since sensed, at least implicitly, that space mattered to radical culture."20 Framing of discourse about drinking - or, more significantly, about choices whether or not to drink alcohol - was influenced by the continued reiteration and re-inscription of the stark contrast between alcoholic ruin and abstinent wellbeing, brought to life in public spaces.

As Thomas Markus has argued, buildings can be seen as narratives and "in space, relations of power are everpresent."21 Prisons and government buildings bear obvious symbolic power, but all buildings make a statement, and operate as a permanent site of display, presenting the power, in this case, of the temperance movement as well as providing an ideal promotional opportunity. Even before the signing of the Preston total abstinence pledge, Livesey had called for the establishment of a place where people could eat, drink, and stay as an alternative to the public house. And indeed on 24 th December 1832 the first such Temperance Hotel opened on Church Street, Preston, to be swiftly followed by similar 
establishments in Bolton, Manchester, Huddersfield, and further afield as the total abstinence movement spread. By 1835 there were at least 22 such businesses in the industrial districts of the North and Midlands, and in 1836 the British Tee-total Temperance Coffee-Rooms and Hotel opened in London. The spread of such businesses kept pace with the rapid growth of the temperance movement and, according to the architectural historian Andrew Davison, temperance hotels existed in all large towns and most of the smaller ones by the end of the 1850s.22 In Bristol, for example, a temperance hotel opened in 1836, and by 1868 there were 13 of them. In 1878 the City Hotel in Manchester was advertised as "'the largest and best arranged non-licensed hotel in the Kingdom" [sic italics] Built at a cost of nearly $£ 30,000$, it boasted quiet and wellappointed public rooms and bedrooms, plus extras such as "electric bells, hot air, and all modern appliances."23 Such was the eventual public presence of these hotels that companies managing them, or compiling guides, flourished. The 1888 edition of Hawes' Handbook to Temperance Hotels, for example, showed twenty three in London, eight in Glasgow, nine in Edinburgh and six in Manchester. ${ }^{24}$

The growing number of teetotallers also needed places to hold their regular meetings. The Preston group, for example, had originally met in the old Cockpit, given to the town by Lord Derby, with its circular tiered seats designed to offer a 
view of the excitement beneath. But dedicated premises were soon felt necessary, and in 1834 the first Temperance Hall was opened in Garstang, Lancashire, ten miles north of Preston, to be followed by many in Lancashire and Yorkshire in the following two decades, some of which remain as visible relics today. The initial money to erect such buildings was usually provided by local subscription, bazaars, and other fundraising efforts, but they proved expensive to maintain and therefore income was often needed from other groups using the premises, or attracting a wider public to less-serious events than temperance meetings. The Temperance Hall in Leicester, founded in 1853 by Thomas Cook, could seat 1,800 people and in the 1890s offered programmes of a music hall type, featuring acts such as the Moore and Burgess Minstrels.25 By 1900 most towns and cities had such a proudly-blazoned Temperance Hall, standing as a mute advertisement and known and recognised by a wider community than merely the convinced teetotallers. Often maintenance became a problem, however, as rather than being commercial propositions, they were usually dependent on the contributions of local supporters.

Public houses did not merely supply lodging, eating and meeting places, however; a main attraction was, after all, the drink on offer. At a period where water was not always a safe, let alone attractive, alternative to alcohol, brewed drinks were on offer in coffee and cocoa houses and tea rooms. These 
were initially small businesses and demanded low investment, but their popularity, and the need for a more impressive or attractive alternative, led temperance promoters to think on a larger scale. Dundee's Temperance Public House (1853) boldly adopted the name of the opposition, and there were at least two more, in Manchester and London. Acting on this example, The British Workman, a leading temperance periodical (18551892) lent its name to a campaign and the actual buildings, with British Workman's Public Houses in Leeds (1867) and other northern towns. By 1892 the Liverpool British Workman Public House Company had 92 such pubs in the area, for example. The adoption of the term "public house" for temperance establishments was a bold stroke typical of temperance campaigners - not merely signalling that the businesses were intended as a replacement, but asserting that these places were indeed open to the public, rather than for members of the temperance movement only. There was even a trade association for these businesses, the Coffee Public House Association (founded 1877), which included businesses using the other main terms, Coffee Tavern, Coffee House, and Coffee Palace. Coffee enjoyed a renaissance in the early nineteenth century: London had only a dozen coffee houses in 1815, but nearly 1,800 by 1840, for example, and when the social reformer Dr. Barnardo purchased a Limehouse drinking-haunt called the Edinburgh Castle to transform, which been a gin- 
palace rather than a public house, he renamed it the

'Edinburgh Castle Coffee Palace" (1873).26 Coffee Palaces then proliferated, as did businesses using the more traditional name of Coffee-Houses, with the eighteenth-century cultural and radical associations of this title. Christina Parolin has explored the links of coffee houses with radical movements of the 1820s; "the coffee house embodied the notion of free speech and, from the early eighteenth century, particularly in the metropolis, they provided fertile ground for the discussion and promulgation of political radicalism, atheism and free thought."-27 Either name was used for the often splendid buildings which sought to win public custom. The term "coffee" was used as a symbol: the customer could buy not only coffee, tea and food but temperance drinks such as ginger beer, lemonade, peppermint water, and sarsaparilla. Cocoa was also a popular temperance beverage, and some companies such as the Llandudno Cocoa House Company and Leicester Coffee and Cocoa House Company took this in their titles. The latter provided static and mobile sites for purchasing non-alcoholic drinks in the city from the 1870s, using stalls and carts as well as the more usual coffee houses, as did many individuals or small companies. Coffee stalls, providing warm nonalcoholic drinks for wanderers both by day and night, were a central feature of town and city streets: John Burnett gives an estimate of 300 on the streets of London in 1850, even before the temperance campaigners sponsored them, when numbers 
rose dramatically. ${ }^{28}$ Insert new Figure 1 pic of coffee barrow The sophisticated example in Figure 1 was the latest thing in 1894, and may well have been operating fifty years later, as the late night coffee stands or carts which were a regular feature of the night scene in large cities until the World War 2 were direct descendants of these temperance enterprises. In terms of public visibility and market reach, these convenient places to eat or drink arguably promoted temperance to more people, long term, than any other aspect of the movement. ${ }^{29}$

When billiards became a fashionable amusement taken up by working men, in the late 1870s, the specialist tables were usually only to be found in public houses. Local temperance societies soon funded the building of specialist temperance billiard halls offering non-alcoholic drinks, and indeed several specialist companies made a thriving business out of this, as villages as well as larger centres decided to invest in a temperance environment in which their young men could play. Andrew Davison points out that Evans used a characteristic design featuring a barrel roof, and several such buildings have survived today - often as pubs. ${ }^{30}$ Further temperance presence on the streets was provided by thousands of statues, water-fountains, and even water-troughs for horses which were donated by local groups or individuals, and bore inscriptions lauding water as an alternative to alcohol - as 
Davison remarks, "temperance had an impact on the streets of our towns and villages ...still widely visible today."31

TEMPERANCE EVENTS

Although buildings and their signs may have offered a permanent reminder, the temperance message was conveyed in a more active mode through temporary events and gatherings. The Crystal Palace grounds at Penge provided large spaces which were popular for national events; in 1857 the Band of Hope organised its first festival at there, with over 3000 children and 1,000 adult supporters, and continued to hold fetes there annually, as did the National Temperance League. More frequently than these huge national events, regional and local groups organised many gatherings which enabled working people to enjoy fresh air whilst learning about temperance. Balloon ascents, sports, musical performances and extra attractions such as photographic galleries were eagerly adopted at an early stage by organisers, and local features were exploited. The poster for the 1850 Annual Temperance Fete and Rural Festival of the Bristol Temperance Society, held in the Zoological Gardens at Clifton Down, featured illustrations of ten of the many creatures to be seen, as well as promises of plants, flowers, promenades, bands and "an abundant supply of provisions" in addition to temperance public meetings in the afternoon and evening. ${ }^{32}$ Excursion trains from as far away as Birmingham and Exeter were also advertised. On a smaller 
scale, in 1858 the Tottenham and Edmonton Temperance Union advertised its "Annual Rural Festival" under the slogan "Holidays Without Headaches." This day, in Downhills, the grounds of stately home in Tottenham, featured a Temperance Brass Band as well as 'cricket, trap ball, archery and other rustic sports', along with donkeys and swings for the children. At $7 \mathrm{pm}$ an open-air temperance meeting concluded the day. ${ }^{3}$ Many of these events offered a substantial tea, either inclusive or at an extra charge such as sixpence, but some societies, aware of financial pressures on visitors, added the kind notification of "hot water provided GRATIS for those who prepare Tea for themselves, in PIC-NIC PARTIES, Beneath their own Tents and Marquees."34

At such events distinctive (and teetotal) musical performances often featured- for example at a Band of Hope fete in Nottingham in 1878, the Holdfast Temperance Campanologists boasted -one hundred silver toned bells, and were celebrating their 300th appearance. They used this information in an advertisement for their services, as well as the fete, and on the same page were also advertised the Criterion Temperance Handbell Ringers and Glee Singers, and the "Silver Chime" Temperance Carillonneurs with their "sweetly toned musical hand-bells."35 But the main group of musicians whose music was perfectly adapted to open spaces was the brass bands. Part of the rational recreation movement, the 
development of brass bands was linked to personal achievement, group endeavour, public entertainment, and of course providing an alternative hobby to drinking. Many of the great brass bands originated as either temperance bands or mining bands and sometimes both. The Wingates Temperance band provides a good example: founded in 1873, it still exists, although now it has sadly dropped the "Temperance" from its name. The huge sound of brass instruments playing together would certainly provide appropriate entertainment for fetes and galas, and some events featured several bands, or competitions.

With large gatherings came the need for transport. Thomas Cook, a total abstainer and lay preacher from Leicester, organised the first all-inclusive trip open to the public, rather than private escorted tours, to go to a temperance meeting. He booked a train in July 1841 to take 500 fellow members to a temperance festival in Loughborough. Each member paid a shilling which included food as well as the 24mile return trip, and cook was left with a profit from the excursion, and a business concept. Recent studies of Cook have emphasised his commitment to enabling people from all income groups and classes to experience the benefits of travel, as part of his wider commitment to rational recreation which included holding all kinds of social meeting, from galas to picnics. ${ }^{36}$ Thirty years later, in 1871 the North London Temperance Society advertised an "Excursion to Crystal Palace 
by Vans" for the annual fete, promising "Choir of 10,000 children, Grand Temperance Fete, Processions with Banners and Bands, all the Great Fountains, Balloon Ascent, Great Organ Performance, Cricket Match, Instrumental Concert, Open Air Meetings, \&c." The vans were to set out at 9 am and return at $8 \mathrm{pm}$, after what sounds like a very full day for the excursionists. ${ }^{37}$ Such excursions became a popular feature of temperance groups' programmes, whether travelling to a meeting or simply sharing a day in the country or at the seaside.

Given the British climate, temperance public events were more usually held inside, in temperance halls or larger public buildings, ranging from the Exeter Hall in London or Free Trade Hall in Manchester to smaller venues around the country. Although these did not take place in public space as such, they were widely advertised as open to the public, and thus also maintained a presence on the streets. Posters survive to witness to the enthusiastic advertising and the variety of events - on Monday evening, January 24rd 1853, for example, a soiree, a musical festival and a bazaar were all held at the Whittington Club on the Strand; the evening included an address by the famous temperance illustrator and speaker George Cruikshank, and "tea, etc on table at 5 o'clock."38 Some events whose titles would have been clear to the nineteenthcentury public perhaps need clarification, now. The festival and tea party can be easily imagined, but the conversazione, 
the soiree and the bazaar are less familiar. A programme for a conversazione in 1862 gives an idea of what visitors could expect: "the rooms, which will be adorned with Plants, Flowers, Paintings, Photographs, Statuary, Models, Curiosities - Ancient and Modern, Microscopes, \&c., will be open for Promenade between 61/2-11, pm'"[sic]. There was music, with a piano, harp and two vocalists, in the upper room, followed by temperance addresses, more music, and a lecture on alcohol, illustrated with chemical experiments. The Upper and Lower Refreshment Rooms served throughout the evening from $7 \mathrm{pm}$ - and all this was in the splendour of the Queens Concert Rooms, Hanover Square, a prestigious venue at which musicians such as Haydn, Mendelssohn and Liszt had performed. ${ }^{39}$ Clearly, moving around between various options for entertainment and mixing with a range of people was usual at a conversazione. The soiree was another form of evening entertainment often held, which seems even livelier, if more static, than the conversazione. A typical programme for one organised by the U.K. Band of Hope Union on January 28th 1880 included songs, addresses, a short concert by the Cardiff National Welsh Choir in full Welsh costume, a display of "Swedish and Musical Drill" by Band of Hope girls, and a 45 minute "Magical Entertainment" as performed before the Royal family - in addition to the presentation of prizes for collection of funds, which was the main purpose of the event. ${ }^{40}$ The audience 
seems to have had less freedom to move around, and more of a programme of performances.

Bazaars were not only intended for entertainment, but offered a fund-raising opportunity which was invaluable. Commercial premises known as bazaars, single buildings filled with stalls let to individuals, became popular in Britain in the 1820s and according to Frank Prochaska the charity version developed almost immediately, and swept the nation: "if the London newspapers advertised over one hundred charity bazaars each year during most of the century, the provincial press probably advertised over one thousand annually." He summarises their widespread appeal, "men and women of all social classes found bazaars, fancy fairs, fancy sales, or ladies' sales as they were variously called, a most popular and fashionable way of making money for the charity of their choice."41 By the time that temperance organisations came into being, the bazaar was well established as a social and money-making event, and formed a staple of social programmes in London and around the country. Some assumed gigantic proportions. In 1875, for example, a six-day Grand Bazaar and Fancy Fair was held at the Great Central Hall, Bishopsgate Street, from 27th December-1st January. Various musical performances enlivened each day, including bands and handbell ringers, and each evening from $6 \mathrm{pm}$ an entertainment programme was given every half-hour, featuring many singers, actors and comedians including Mr 
Frank Hiam in his "Comical, Topical, Whimsical, Farcical, Pantomimical Christmas Entertainment." Other attractions were a large collection of working models, a large collection of curiosities, works of art, dresses, and more, and in yet another room a Magelethescope made in Venice showing "'beautiful illuminated Pictures of France, Italy, Switzerland, \&C." Presents from the Monster Christmas Tree were given away each day - and this was all in addition to the retail opportunities offered by the stalls. ${ }^{42}$ As Prochaska remarks, bazaars (which usually charged an entrance fee of sixpence to a shilling) raised a huge amount of money for their sponsoring charities, and it is a shame that so few records of profits survive for the temperance bazaars. However, a similar, although smaller scale, five-day bazaar in the Free Trade Hall, Manchester, on the theme of "Storyland," in 1909 featured themed stalls, musical entertainments, a shooting gallery and cafes, and raised $£ 5,527$, over $£ 1,000$ a day. ${ }^{43}$

THE SOUND OF TEMPERANCE

Music, often instrumental, was mentioned in connection with almost all public events. But an examination of the importance of singing, and concerts in particular, reveals how deeply the temperance movement relied on music for creating a sense of participation, as well as entertainment. Brian Harrison suggests that the temperance movement, in common with 
similar popular pressure groups, had three main functions, which he sums up as "to inspire, to inform and to integrate."44 Songs, through their lyrics and music, fulfilled all three of these functions. The study of British temperance songs is only now beginning, and this important aspect of popular song, having links with such fields as trade union and religious songs, has yet to be explored. ${ }^{45}$ Whether heard in performance by a professional singer or large choir, or encountered in a child's attempt at a tuneful rendition, the temperance song usually informed (sometimes dramatically warning against drink) and often attempted to inspire, with titles such as "Pull Together, Boys!" and "Forth to the Fight!"46 It might be argued that the shared hearing of these songs reinforced a feeling of belonging to the triumphant movement, but arguably the singing of them was the most integrative way in which temperance songs operated. The temperance community was full of opportunities for amateurs to sing in public, both on the move in the processions and pageants discussed below and in more static surroundings in the many concerts - and indeed, most meetings would begin with a hymn or temperance song. The concerts were perhaps the glory of the temperance movement; the huge open air-ones at the Crystal Palace were the most impressive, for many years featuring three choirs of 5,000 voices each, but many were held in large public buildings in London, Manchester or Birmingham, and at local and regional level there seems to have been almost constant preparation for 
concerts and musical competitions. Magazines, particularly those for children, printed songs regularly, and the many temperance songbooks and hymnbooks printed testify to the desire for a record of known songs, and the regular provision of new ones.

It would have been almost impossible, using conventional musical notation, to share music so widely, but the revolutionary tonic sol-fa system, devised by Sarah Glover (1785-1867), a clergyman's daughter, to help poor children at her school which represented notes by "do, re, me" made such printed music accessible to all. It was further developed by John Curwen (1816-1880) whose publication The Standard Course of Lessons on the Tonic Sol-fa Method of Teaching to Sing (1858) aimed to enable and encourage working people to sing in choirs, and was enthusiastically taken up by many social and progressive groups, particularly temperance societies. ${ }^{47}$ This made it possible both for the individual to gain a wide repertoire of songs, and also for large group choral events to be mounted, with local choirs rehearsing the set pieces in their meetings and then meeting on the day to rehearse together. An example of how such concerts were integrated into other events can be given in a report from Accrington in 1888, "the principal feature in the work of last year was the very successful flower festival, in which over 200 little girls formed the choir, and which provided funds sufficient to 
enable the committee to offer free a dissolving views [magic lantern] entertainment to every society in the Union."48 The magic lantern was widely used the movement, and the Band of Hope became the largest supplier of slides. Weather permitting, shows were even held outside in public spaces, with images projected onto sides of buildings or special vans equipped for the purpose, providing a popular and dramatic way to spread the temperance message. ${ }^{49}$

TEMPERANCE ON THE MOVE

As previously mentioned, temperance musicians were not always static: some of the singing, playing and bearing public witness to temperance accompanied events which took place on the move. These were variously named, but could be summed up as marches, parades, processions, and pageants. Such perambulations offered the advantages of other temperance public gatherings, that is, entertainment, mutual support, reinforcement of commitment and publicity for the cause, but particularly the last-named benefit. Temperance campaigners were most visible to non-abstainers when they took to the streets en masse, and the alternative teetotal world intersected dramatically with the "mainstream" one. An excellent example of this can be seen today, as there is a 1901 five minute film by Mitchell and Kenyon publicly available. 50 The long procession clearly takes beyond the five minute period of the film to pass the camera, and the huge 
crowds testify to the public reach of such demonstrations. Paul o'Leary in his study of similar nineteenth-century processions in Wales comments, 'walking the streets with others on special occasions, dressed in particular ways and carrying banners, regalia and insignia, transforms how an event is experienced and turns it into the representation of an idea.' 51

Processions had been a feature of the early days of the teetotal movement, in a distinctive and often challenging form. Rattles were used to attract audiences, as well as music, and "reformed drunkards" parading their new, sober, status formed the main feature of the procession. The vigour was still evident twenty years later in Tredegar, in 1859, 'the effect this [procession] had on the town was electrifying. Temperance societies and choirs were established and enthusiastic meetings were held. ... Such events provided the impetus for the building of a Temperance Hall by public subscription.'52 When, by 1870, public displays had become more respectable, Livesey lamented the loss of this dimension, as it had served as "a living, moving, lecture in the face of all men."53 Indeed, the distinction between the many forms of public display became blurred as the century continued, and in some cases terms seem to have been used relatively interchangeably on illustrations and in records. However, to establish a distinction, I would take a demonstration or march 
to be the most formal and serious activity, with participants often on their way to a meeting where policy or issues would be discussed. A procession might have a slightly more celebratory tone, and was perhaps more likely to be for the entertainment of those involved, although still dedicated to a serious end. An 1878 meeting in Hyde Park of the League of the Cross, the Catholic temperance organisation founded in 1873, was preceded by such an event, termed as both march and procession in the announcement below:

All the branches will assemble about noon on the Victoria Embankment, and proceed by Whitehall-place, Charing-cross, Pall Mall, and Piccadilly to the park [...] The march will be enlivened by the music of twenty-two bands, and each branch will have its banner carried in front of its body. Sir Edmund Henderson, Chief Commissioner of Metropolitan Police, has promised the assistance of his men to preserve order along the line of procession. -54

Although no numbers are mentioned, the twenty two bands mentioned indicate a substantial gathering, and the League of the Cross was one of the smaller temperance organisations; moreover, the temperance movement was nowhere near its zenith in 1878 . 
Parades and pageants were also public displays, and Figure 2 shows some little girls at an occasion which might fall under either heading. O'Leary alludes to the North American parade as a more disciplined and purposeful, almost military, demonstration, but the word seems to have connoted a less organised event in the UK.55 A parade was a more festive occasion than a demonstration or march, with participants dressed either in their best or in costume, and could include "floats" - in the nineteenth century horse-drawn carts, or drays. From records and illustrations it appears that a pageant's distinctiveness is that it would usually be performed in a specific space, with the audience usually seated, and have a definite theme, with members in costume or supporting themed displays. The photograph above, if examined carefully, reveals a body lying on the ground in the centre foreground, and the girl centre right is holding a large pantomimic bottle labelled "Gin," so this may well have been a pageant - or a procession or parade to the eventual site of one. Reports of children's pageants abound, such as Juvenile Rechabites dressed up to represent some of the many countries in which the movement was strong, or children choosing a theme such as "Prevention is Better than Cure." Whether such displays were termed parades or pageants, they seem to have been very popular with both children and public spectators and, like similar public events today by groups such as LGBT Pride, they were occasions where the group could not only 
assert its right to the street space, but display its lighter side and reduce possible public hostility.

THE DISPLAY OF TEMPERANCE

A key element of performance is costume, and here I refer to wearing the recognisable insignia of an organisation. As Bourdieu posited, distinction is a common desire, and the wearing of medals, badges, collars, and other regalia not only distinguished the wearer from non-members and within the organisation, but provided publicity for the cause. ${ }^{56}$ Most organisations adopted such markers, reflecting systems which drew from military hierarchy. The Band of Hope, for example, had several membership medals throughout its long history, but during the late nineteenth century the "Holdfast" long service system was developed, in which the child was awarded a medal for the first year's attendance and a bar for every subsequent year, up to seven years. After gaining six bars on the medal ribbon displaying achievements such as "two years prayerful," the member would be eligible for a "long service" medal. Children and adults were encouraged to wear their medals or badges on every possible occasion, but some of the adult temperance organisations had more elaborate regalia which they wore in public at specific events. The great temperance friendly societies, such as the Rechabites or sons of Temperance, adopted many masonic traditions such as chains of office, sashes, collars and aprons and when Rechabites, for 
example, attended marches or parades as a group they would make a strong impression. In fact this group, named in honour of the sons of Rechab who would drink no wine (Jeremiah 35:6), developed the most impressive public symbol, used to advertise the organisation, to arouse interest, to encapsulate temperance teaching, and to make them instantly recognisable.

\section{Insert New Figure 3, Rechabite emblem}

Figure 3 shows the Rechabite emblem, used on banners, posters, badges, textiles, sets of china, and almost every item associated with the society. Stained glass windows, for example, each featuring an individual symbol, presented this emblem permanently to passers-by at the headquarters on Deansgate, one of the main streets in Manchester.57 By 1840, five years after the order was founded, the main symbols were already being used to represent the fruits of temperance, and they were later agglomerated to produce the full emblem. The two main figures, Peace and Plenty, represent the benefits of not drinking for the household. Peace is holding an olive branch, also seen replacing a sword on her right, and Plenty carries the traditional cornucopia. Bees, for industry, reflect the working-class origins of the group, and the temperance lifeboat appears again at the bottom right. Some symbols are biblical; Noah's Ark, at the bottom, the lamb of God and the eye of God in the centre and, beneath this, the tents of the original desert-dwelling sons of Rechab. This 
magnificent emblem was seen to great advantage on banners, the largest and most visible form of insignia, and indeed temperance banners from many groups drew on the traditions of trade union banners as well as those of religious iconography, and brought temperance to public spaces dramatically. Rechabite presence at public events such as those discussed here would not only feature the emblem on large banners and their smaller, individually carried, version, bannerettes, but large metal models of each symbol would be carried high on poles by members, effectively decoding the emblem for the viewing public.

The many groups making up the temperance movement created a powerful presence in most conurbations in the second half of the nineteenth century and beyond, and this brief survey raises the need for further research. This article has begun to establish a taxonomy of the public display of temperance, although categories overlap, as with many human endeavours. Although those who embraced the temperance cause have been described as creating an alternative world, in fact the abstainers, their buildings and their events, would have been very publicly visible to all who used public space. This may well have acted as an irritant to the confirmed public drinker, and the debate about alcohol consumption was very much part of the culture of the streets for much of the nineteenth century. The common conviction of members of 
temperance organisations may have sprung from a negative position, that of not drinking, but they certainly did not settle for passive, quiet, or merely pious, opposition to drink; they engaged in active assertion. Alcohol was seen as destroying individual lives, families, and communities - and this belief came, in many cases, from bitter experience. Therefore the abstainer had a duty to bear witness to the dangers of drink, and to attempt to save others, as a social and public duty. The urban historian Lewis Mumford argues that the city is "a theater of social action," and, if so, we must devote more attention to the complex part which the teetotal movement played on its stage in the nineteenth century. ${ }^{58}$ 
Endnotes

1 Joseph Rowntree and Arthur Sherwell, The Temperance Problem and Social Reform Eighth edition (London: Hodder and Stoughton, 1900), 5 .

2 Peter G. Goheen, "The ritual of the streets in midnineteenth-century Toronto" Environment and Planning D: Society and space 11(2)(1993), 128.

3 Virginia Berridge, Demons: Our changing attitudes to alcohol, tobacco, \& drugs (Oxford, Oxford University Press, 2013), 38. 4 See Brian Harrison, Drink and the Victorians: The Temperance Question in England 1815-1872- Second edition, (Keele: Keele University Press, 1994); James Nicholls, The Politics of Alcohol: A History of the Drink Question in England (Manchester: Manchester University Press, 2011). 5 Joseph Livesey, Reminiscences of Early Teetotalism (Preston and London: The Staunch Teetotaler and Tweedie, 1868), 4. 6 Ibid, 15.

7 Ibid, 29.

8 Trygve Tholfsen, Working Class Radicalism in Mid-Victorian England (London: Croom Helm, 1976), 239.

9 The Templar of Wales, 6 september 1873, cited in Harrison, Drink and the Victorians, 126.

10 Wyn Grant, Pressure Groups, Politics and Democracy, Second edition (London: Macmillan, 1995), 15-23.

11 Harrison, Drink and the Victorians, 130.

12 Lilian Lewis Shiman the Crusade Against Drink in Victorian England (London: Palgrave Macmillan, 1988); Paul O'Leary, Claiming the Streets: Processions and Urban Culture in South Wales, c.1830-1880 (Cardiff: University of Wales Press, 2012). 13 Andrew Davison, "'Try the alternative': the built heritage of the temperance movement," Brewery History No. 123 (Summer 2006) : 92-109. 
14 Jack Blocker, Alcohol, Reform and Society: The Liquor Issue in Social Context (Westport, CT: Praeger, 1979), xiv. 15 Blocker, Alcohol, Reform and Society, 45: Ian Tyrrell, Sobering Up: From Temperance to Prohibition in Antebellum America, 1800-1860 (Westport, CT: Praeger, 1979), 167. 16 Paul D. Sanders, Lyrics and Borrowed Songs of the American Temperance Movement (Columbia, MO: University of Missouri Press, 2006), 4 .

17 George W. Ewing, The Well-Tempered Lyre: Songs and Verse of the Temperance Movement (Dallas, Southern Methodist University Press, 1977); Joseph R. Gusfield, Symbolic Crusade: Status Politics and the American Temperance Movement (Champaign, Il: University of Illinois Press, 1970); Scott C. Martin, Devil of the Domestic Sphere: Temperance, Gender, and Middle-Class Ideology, 1800-1860 (De Kalb, Il: Northern Illinois University Press, 2008).

18 Sharon Zukin, Landscapes of Power: From Detroit to Disneyworld (Berkeley: University of California Press, 1991). 19 Jurgen Habermas, The Structural Transformation of the Public Sphere: An enquiry into a category of bourgeois society, trans. Thomas Burger (Cambridge Mass: MIT Press 1989), 51-59. 20 Christina Parolin, Radical Spaces: Venues of Popular Politics in London, 1790-C1845 (Canberra: Australian National University Press, 2010), 7 .

21 Thomas Markus, Buildings and Power: Freedom and Control in the Origin of Modern Building Types (London: Routledge, 1993): 5,23 .

22 Davison, "Try the Alternative."

23 The Temperance Record, 6 June 1878, 367.

24 C.W. Hawes, Hawes' handbook to Temperance Hotels (London: National Temperance Publication Depot, 1888): 13-14, 10, 9, 14 . 
25 I am grateful to the Arthurlloyd.co.uk Music Hall and Theatre History website not only for this information but for extending my knowledge of Music Halls.

26 Coffee house figure from Hugh Cunningham, Leisure in the Industrial Revolution (London: St Martin's Press, 1980), 308. 27 Parolin, Radical Spaces, 214.

28 John Burnett, Liquid Pleasures: A Social History of Drinks in Modern Britain (London: Routledge, 1999), 84. Burnett points out that the progressive lowering of duty on coffee in 1825 and 1842 had also contributed to the tremendous popularity of public coffee drinking, but acknowledges the driving force of the temperance movement (83-84). 29 Some survive in London; for example, there is one on Russell Square still providing coffee to passers-by .

30 Davison, "Try the Alternative," 107-8.

31 Ibid, 109.

32 Poster for 1850 Annual Temperance Fete and Rural Festival of the Bristol Temperance Society, John Johnson Collection of Printed Ephemera, Bodleian Library, Oxford.

33 Poster for 1858 Annual Rural Festival, Tottenham and Edmonton Temperance Union, in John Johnson Collection. 34 Poster for Oxford Temperance Festival, 7 August 1869, in John Johnson Collection.

35 All the above examples from the advertisement columns of The Temperance Record, 6 June 1878, 365.

36 Michele M. Strong, Education, Travel and the "Civilization" of the Victorian Working Classes (London: Palgrave Macmillan, 2014), 23-25; Piers Brendon, Thomas Cook: 150 Years of Popular Tourism (London: Secker \& Warburg, 1991), 28.

37 Poster for North London Temperance Society Excursion, 1871, in John Johnson Collection.

38 Poster for London Temperance League event, January 24 1853, in John Johnson Collection. 
39 Programme for National Temperance League Conversazione, 24 May 1862, in John Johnson Collection.

40 Programme for United Kingdom Band of Hope Union, Annual Soiree, 28 January 1880, in John Johnson Collection.

41 Frank Prochaska, "Charity Bazaars in Nineteenth-Century England," Journal of British Studies 16 (Spring 1977): 62-84, 66,62 .

42 Poster, "A Great Treat for the Christmas Holidays," 1875, in John Johnson Collection.

43 Annual report, United Kingdom Band of Hope Union, 1909-10, copies held by Lambeth Palace Library.

44 Brian Harrison, "Press and Pressure Group in Modern Britain," in The Victorian Periodical Press: Samplings and Soundings ed. Joanne Shattock and Michael Wolff (Leicester: Leicester University Press, 1982), 282.

45 See Annemarie McAllister, "Temperance Battle Songs: the Musical War against Alcohol," Popular Music, forthcoming special edition on "Music and Alcohol"(2016).

46 These songs were published in the magazine Onward in January 1870 (pp.8-9), and September 1890 (pp.136-7), respectively. 47 See Charles McGuire, Music and Victorian Philanthropy: The Tonic Sol-Fa Movement (Cambridge: Cambridge University Press, 2009).

48 Annual report, United Kingdom Band of Hope Union, 1888, 40. 49 For magic lantern performances see Annemarie McAllister, "'To assist in the pictorial teaching of Temperance': the use of the Magic Lantern in the Band of Hope" in Screen Culture and the Social Question, 1880-1914, ed. Ludwig Vogl-Bienek and Richard Crangle (London: John Libbey Publishing, 2013). 50 'Manchester Band of Hope Procession(1901)'Available at http://www - youtube.com/watch?v=h5XPJ2RcavI Accessed 13.10.15. 51 O'Leary, "Claiming the Streets," 18 . 52 Ibid, 116. 
53 The Temperance Star, 14 April 1870, 7.

54 The Temperance Record, 6 June 1878, 363

55 O'Leary, Claiming the Streets, 2.

56 Pierre Bourdieu, Distinction: A Social Critique of the Judgement of Taste (London: Routledge and Kegan Paul, 1984), 57.

57 Photographs of these windows can be seen in the "Picturing Temperance" section of the virtual exhibition at http://www.demondrink.co.uk.

58 Lewis Mumford, "What is a city?" in The City Cultures Reader, ed. Malcolm Miles, Tim Hall and Iain Borden (London: Routledge, 2004), 29. 